вона є ключовим складником, який вимагає від учителя професійно значущих знань, умінь i навичок, спеціальних якостей i здібностей задля успішної організації молодших школярів.

Зважаючи на історичний досвід i сучасні дослідження, основною метою краєзнавчої роботи вчителя початкових класів загальноосвітньої школи необхідно вважати створення та роботу з краєзнавчим музеєм при закладі освіти, оволодіння краєзнавчими знаннями, усвідомлення ними їх духовної значущості. Зміст краєзнавчої діяльності майбутніх педагогів повинен передбачати: оволодіння знаннями про роботу і структуру краєзнавчого музею, краєзнавчими знаннями 3 літературних й інших джерел інформації шляхом безпосереднього вивчення регіону; використання краєзнавчих знань у навчально-виховній роботі; організацію краєзнавчої роботи з учнями в позаурочний час. На сучасному етапі цій проблемі приділяється багато уваги і помітні позитивні зміни прогресиввного характеру.

\title{
Література
}

1. Грушевський М. С. Ілюстрована історія України / М. С. Грушевський. - К. : Наук. думка, 1992. - 543 с. 2. Коваль Л. В. Професійна підготовка майбутніх учителів початкової школи: технологічна складова : [монографія] / Л. В. Коваль. - Донецьк : Юго-Восток, 2009. - 375 с. 3. Назаренко С. Використання потенціалу музеїв у навчально-виховному процесі / С. Назаренко // Історія України. - 2013. - № 1. - С. 14 16. 4. Стельмахович М. Г. Українська родинна педагогіка / М. Г. Стельмахович. К. : ІСДО, 1996. - 288 с. 5. Ушинський К. Д. Твори в 6-ти томах / К. Д. Ушинський. К. : Рад. шк., 1995. - Т. 6. - С. 562-566. 6. Энциклопедический словарь / под ред. И. Е. Андреевского и проф. Ф. Ф. Петрушевского. - СПб. : Изд-во Ф. А. Брокгауза и И. А. Эфрона, 1901. - Т. 66. - С. 693-694.

УДК 373.5.016:821.161.2.0

Жанна Свірська

\section{ПРОБЛЕМИ ВДОСКОНАЛЕННЯ ЗМІСТУ І СТРУКТУРИ ПРОГРАМ ТА ПІДРУЧНИКІВ ІЗ ЛІТЕРАТУРИ У ВИСВІТЛЕННІ ЄВГЕНА ПАСІЧНИКА}

Свірська Ж. М. Проблеми вдосконалення змісту і структури програм та підручників із літератури у висвітленні Свгена Пасічника.

У статті здійснено спробу висвітлити системний підхід фундатора методики навчання української літератури професора Є. Пасічника в концепцію шкільної гуманітарної освіти. Автор зосереджує увагу на принципах створення змісту, структури підручників та ролі програмових документів як сталих складових літературного розвитку школярів.

Ключові слова: методична система навчання літератури, науково-методична школа, системний підхід, концепція, літературний розвиток, читацька діяльність.

Свирская Ж. Н. Проблемы усовершенствования содержания и структуры программ и учебников по литературе в освещении Евгения Пасичника.

В статье сделано попытку отобразить системный подход Е. Пасичника в концепцию школьного образования. Автор заостряет внимание на принципах содержания, структуры учебников, роли программных документов как составляющих литературного развития школьников.

Ключевые слова: методическая система изучения литературы, научнометодическая школа, системный подход, концепция, литературное развитие, 
читательская деятельность.

Svirs'ka Z. M. The problems of the content and structure improving of literature curriculum and textbooks in coverage of E. Pasichnyk.

The article is an attempt to highlight the systematic approach of the concept of humanitarian education school by the founder of method of teaching Ukrainian literature professor E. Pasichnyk. The author focuses on the principles of creating content, structure of textbooks and role of curriculum documents as a constant part of pupils literature development.

Key words: methodological system, scientific-methods school, comprehensive approach, concept, literature development, public activity.

Утвердження позицій методики навчання української літератури в Україні пов'язано 3 іменем доктора педагогічних наук, професора Євгена Андрійовича Пасічника. Його методична система пройшла складний еволюційний шлях, набувши концептуальності й структурної довершеності, що знайшло втілення в педагогічній діяльності, методичних статтях та книгах як теоретичного, так i навчального характеру, програмових матеріалах. Піднявшись до рівня теорії, науковець висунув теоретико-методологічні положення, принципово важливі для розвитку і методичної науки, й літератури як навчальної дисципліни.

Відображення в творчому доробку Є. Пасічника ключових проблем сучасної методики літератури, зосібна формування читача, простежується у розвідках О. Ісаєвої, О. Гаврилюк. Оцінку науково-педагогічної спадщини методиста щодо сприйняття учнями духовних орієнтирів творчості письменників утілено в статті Т. Чумак.

У світлі дидактичних концепцій науковця проаналізовано особливості плекання ціннісних орієнтацій школярів засобами літератури (В. Варенко, Л. Козубенко та ін.). Технологічні підходи Є. Пасічника до системного вивчення драматургії 3 урахуванням її міжвидової природи бере за основу А. Вітченко. Спробу осмислити й узагальнити досвід методиста щодо опрацювання прози роблять Н. Буркалець, К. Каплюк. Поради Є. Пасічника та Б. Степанишина учителям щодо специфіки осягнення ліричного твору порівнюють Н. Черниш, М. Турчин та ін.

У дослідженнях Ю. Бондаренка висвітлено погляди провідного методиста на застосування у шкільній практиці філософсько-історичних основ аналізу художніх творів, окреслюються перспективи такої роботи.

Розв'язання досліджуваної проблеми започатковано в публікаціях О. Куцевол, Ю. Романенка, Г. Токмань, В. Шуляра. Науковці здійснюють проекцію ідей науковня на сучасний стан методики навчання літератури.

Моделювання освіти неможлива без осмислення попереднього історичного досвіду, перспективних ідей учених, що дозволяє не тільки зрозуміти діалектичну сутність навчального процесу, а й прогнозувати тенденції педагогічних інновацій. Отже, потреба в грунтовному розумінні потужного пласту минулого цілком очевидна. А між тим, історія української методичної науки переживає не ліпші часи.

Необхідно визнати, що російські дослідники надають значну увагу етапам становлення методики навчання літератури. Відтак ця проблематика не може похвалитися такою ж зацікавленістю 3 боку вітчизняних здобувачів наукових ступенів. Достоту, відсутність фундаментальних робіт про розвиток науковометодичних шкіл негативно відбивається на теорії прогнозування гуманітарної освіти учнів. 
Наразі не вповні простежено, як формувався та знаходив вияв системний підхід професора Є. Пасічника до вдосконалення змісту шкільної літературної освіти в першому десятилітті XXI ст. Уважаємо за необхідне продовжити наукові розробки, щоб узагальнити досвід методиста в галузі шкільних навчальних видань, що й мотивувало вибір теми дослідження.

Mema cmammi - проаналізувати внесок Є. Пасічника в удосконалення змісту й структури програм та підручників з української літератури як сталих складників громадянського, національного, художньо-естетичного та морально-етичного виховання учнів.

За результатами проведеного опитування учителів робимо висновок, що загалом вони знайомі $з$ працями науковця. При цьому його більше знають ті, що розпочали свою діяльність у 80-ті роки ХХ ст. Загальне визнання кількох поколінь студентів вищих закладів освіти одержав підручник «Українська література в школі» [1]. У вітчизняній методиці на той час не було розроблено основ шкільного вивчення літератури, стрункої таксономії методів, які забезпечують результат на різних етапах літературної освіти школярів. Автор підручника корегує понятійну базу, моделює структуру нових різновидів уроків з опорою на традиційні прийоми навчання.

Зі здобуттям Україною суверенітету в державі йде переоцінка всіх духовних вартостей, відбуваються кардинальні суспільні перетворення. Відповідно, теорія й методика навчання української літератури набуває нових методологічних основ, пов'язаних із деідеологізацією та національним відродженням. За тим, шкільна освіта потребувала нового нормативно-правового, науково-методичного забезпечення, важливими компонентами якого є програмові документи, підручники та навчальні комплекси.

Запропоноване Є. Пасічником бачення в посібнику «Методика викладання української літератури в середніх навчальних закладах», який став підсумковим у творчій біографії науковця, орієнтувало вчителів на творче осмислення спектру питань, пов'язаних із формуванням світоглядних орієнтацій особистості, розвитком їі духовного потенціалу [3]. Думка теоретика торкнулась усіх найпомітніших здобутків у методичній царині, а практичний досвід учителя надав змогу висувати сміливі гіпотези, що перевірялися його послідовниками в науково-методичній школі та успішно втілювалися в освітній процес. Словесники, які використовували книжку нового покоління, знайомилися 3 варіативними шляхами аналізування текстів, озброювалися комплексом прогресивних форм проведення навчальних занять із літератури. Однак ця праця не перевидавалась, а коло прихильників педагогічного таланту С. Пасічника з часом дещо звужувалося.

У науковій школі висуваються гіпотези, концепції, теорії та не бояться дискусій, опонентів - тут має бути все для свободи творчості. Упродовж багатьох років Є. Пасічник опікується майбутнім шкіл країни. Поряд із літературознавцями, письменниками, учителями-словесниками він активно виступає на конференціях, семінарах, нарадах, що проходять у різних регіонах України. Обшир бібліографії свідчить про глибоку оцінку наукових дискусій, в основі яких лежать дражливі питання громадянського, національного, художньо-естетичного та моральноетичного виховання.

Зосібна, у фаховій пресі методист оприлюднює вагомі напрацювання щодо вдосконалення змісту й структури програм, підручників із літератури як сталих складників навчання i виховання. Критична спрямованість низки публікацій, пронизаних інтонацією переживання, дає чітке уявлення про істотну різницю та принципові розбіжності його методичної системи 3 окресленими лініями шкільної 
підготовки учнів. Міністерство освіти й науки не враховує «виправданої роками триваріантності програм» [7, с. 17].

Науковцем зауважено, що в літературній освіті, яка визначає рівень духовного здоров'я нації, намітилися небезпечні тенденції. Євген Андрійович переймався тим, що ідея гуманітаризації, складником якої $є$ виховання громадянина через літературне читання, поступилася місцем ідеї «прагматизації» освіти. Цілком логічно це поступово призвело до скорочення годин у навчальних планах. До слова, за радянської доби українській літературі відводилося 4 години на тиждень, згодом - 3, а після відповідного реформування - 2. За таких умов опрацювання художніх творів уповні співвідноситься 3 приказкою «біг пес крізь овес», тим паче, коли імена письменників та їх мистецьких полотен змінюються чи не щоуроку.

У численних виступах перед освітянами методист, який пройшов шлях від рецензента до автора шкільних програм і підручників, протестує проти подальшого скорочення часу на опанування предмета. Занепокоєння викликало те, що учні заледве встигають читати, не йдеться про «занурення» в мистецький витвір, осмислення змісту й форми як визначальної основи естетичної цілісності літературного твору, про усвідомлення місця й ролі важливих складників тексту. Відтак, і прогресивні технології на літературних заняттях є безсилими.

Є. Пасічник зауважив, що альтернатива вибору програм і підручників - звична практика світу. Це - норма, що не різночитань у літературну освіту дітей у цивілізованих країнах, оскільки базується на чітких освітніх стандартах і передбачає базові навички, вміння, якими оволодіють школярі. А головне - варіативність забезпечує право авторам на змагання. Тоді як відсутність кількох програм із навчальних предметів, тим паче з літератури, за влучним висловом професора,«крок назад, а не вперед у системі освіти», бо унеможливлює здорову конкуренцію, гальмує рух по висхідній. За «єдиними» вказівками, що довела практика радянської школи, закласти в людині основи громадянськості й духовності важко [6, с. 49].

Стурбованість посилювало те, що у процесі проведення конкурсу на якісний підручник i кращу програму 3 української літератури його організатори не дотримувались демократичних правил. Широке коло педагогів не мало можливості висловитись про їх якість.

Учителю в школі буде добре лише тоді, коли він буде мати переважне право на ту ступінь свободи, яка необхідна для творчої людини. Що саме під цим розумів методист? Передусім, у вчителя-словесника має бути можливість не лише обирати технологію проведення уроку, а самостійно доповнювати програму. Нашим освітянам не можна силою нав'язувати підручник - безумовно, вчителі спроможні самостійно вирішити, яка 3 книг цікавіша, доступніша для цільової авдиторії. До того ж, розмаїття навчальних книжок створює оптимальні умови для виховання підлітків, автоматично розвиває читацькі уподобання [4; 6; 7].

Нині право педагога на вибір концепцій, навчальних програм і посібників закріплено чинним законом про освіту. Однак шкіл, які неухильно дотримуються цього закону, мало, тут аж ніяк немає відповідності.

Створення доброякісних програм і підручників,- державна справа, - робить висновок Є. Пасічник [6, с. 50]. Концептуально довівши цю тезу, він звертає увагу на шляхи подолання проблем нової доби.

Низка праць, оприлюднених у провідних часописах, на шпальтах газети «Дзеркало тижня», відображає незадоволеність фахівця якістю шкільної програми 3 української літератури. У статтях «Варіативність програм і підручників - це крок вперед чи назад?», «Ясла повні(?.)» та «Міністр пропонує школярам малювати 
горщечки?» методист висуває ідеї, якими слід послуговуватись усім, хто надумає розробляти програмові документи [6;7;8].

Прагнення до системності, а відтак, до міцності знань, на шкоду принципу природовідповідності в навчанні призводило до того, що з процесу літературної освіти випадала центральна ланка - учень. Саме розвиток учня 3 неповторним внутрішнім світом, читацькими уподобаннями визначав науковий інтерес та напрям логічно струнких досліджень $Є$. Пасічника.

Актуальною нині залишається критика, висловлена на адресу групи розробників програми для загальноосвітніх навчальних закладів за загальною редакцією Р. Мовчан. Одна зі статей містить застереження вченого, що документ «укладали автори, які ніколи не працювали в школі, а тому не знають особливостей сприймання учнями літератури як навчального предмета, не врахували інтересів дітей, їхніх запитів» [8, с. 11]. Подивування викликало те, що запропонований для опрацювання пласт дитячої літератури у багатьох випадках недоречний, а то й убогий за рівнем художності $[6 ; 8]$.

Невід’ємним компонентом виховання на уроках літератури «вчитель учителів» визначає емоції, які, на його думку, повинні супроводжувати весь процес художнього пізнання. Вони є рушійною силою будь-якого виховного процесу. Настановними стали ідеї, що вивчення літератури традиційно носить скоріше пізнавальний, аніж виховний характер. Чинна програма не вповні відповідає запитам творчо інтерпретувати художні тексти, а значить, і потребам часу. «Чи варто включати до програми для текстуального вивчення в шостому класі оповідання «Дивак»,висловлює сумнів методист. Адже молодшим школярам нерідко незрозумілий підтекст твору. Читаючи його, «діти зосереджують увагу не на вчинках неординарного хлопчика, що сприймає навколишній світ не так, як інші діти. Те, що найбільше їм запам'ятовується, - це нерозумна поведінка вчительки» [8, с. 11].

Євген Андрійович експресивно обгрунтовує думку, що сучасним підліткам не припадають до душі тексти з пласкими темами, не знаходять емоційного відгуку віддалені в часі реалії життя. Наприклад, «Торфоперегнійні горщечки прославляли на повну силу і в пресі, і по радіо та телебаченню давно, ще в радянські часи. Їх називали «чудом віку» [8, с. 11]. Отже, те, що років 20-30 тому, було доречним, привертало увагу, зараз безповоротно втратило суб'єктивну значущість. А тому відповідний твір під час опрацювання не викликає в читачів переживань і асоціацій: змінилися проблеми, якими жило суспільство, - мусить змінитися література [2, c. 50].

Прихильник естетичної концепції, заперечував тезу про те, що літературі треба навчити, Є. Пасічник пріоритетною вважав мистецьку сутність художнього тексту. Як типова хиба науковцем зауважено той погляд на дитячу книжку, яка не бентежить, допомагає пережити, а мусить повчати. Досвідчений педагог не раз підкреслює, що необхідно орієнтувати учнів не на бесіду про зміст прочитаного, а, насамперед, акцентувати увагу на особливостях літературного твору, які виходять за межі окремого хронотопа й тяжіють до вічних художньо-естетичних та моральноетичних цінностей.

Серед прикрих серйозних прорахунків авторського колективу те, що у оновленій програмі для текстуального аналізу рекомендовано перелік творів, які направду не сприяють морально-етичному й естетичному вихованню школярів. Натомість, націєтворчі, ті що консолідують, у країні, де гуманітарна політика далека від україноцентричних зусиль, - нечисленні [2].

Звичайно, можна називати твори, які можна додати або вилучити, які теоретичні 
поняття прибрати. Втім, це радше суб'єктивне бачення розробників документу. Змінювати треба підхід, - переконує професор. Укотре програма засвідчує значну кількість персоналій авторів, що, властиво, відсуває на другий план вивчення поетики художнього тексту. Безперечно, за цих умов годі очікувати поважного, животрепетного ставлення до книги.

Авторові низки публікацій аж ніяк невмотивованою видається позиція, коли задля прагнень уникнути перевантаження програми, вилучаються визнані твори метрів української словесності XX століття. Укладачі програми мають враховувати такий важливий чинник, як оптимістичне сприйняття школярами середніх класів життя, їхнє бажання читати насамперед твори зі щасливою розв'язкою, захоплюватися пригодами своїх літературних ровесників, смішними історіями. За Є. Пасічником, мають репрезентуватися тексти вищого гатунку, які не ранять психіку дитини та не руйнують чарівного світу дитинства.

Було би правильним, щоб над програмою працювали передовсім ті, хто має досвід укладання програм, і знає про що говорити 3 підлітками. Учений наполягав, щоб головними були естетичні категорії, за ними добирались і апробована класика, й перевірені читацькою любов'ю сучасні зразки рідної літератури. Ця вимога здається цілком справедливою. Як показав осмислений історичний досвід, переважно пряме перенесення літературознавчої науки в школу є неплідним як для вихованців, так i для методики [6, с. 49].

Слід визнати, що системних відповідей на порушені питання не маємо.

Зрозуміло, що всі проблеми методичного поступу та шляхи шукань Євгена Пасічника не можна розглянути в першому наближенні та в одній розвідці. Слушним $\epsilon$ усвідомлення, що творчий доробок професора, який примножив інтелектуальні досягнення нації в гуманітарній освіті залишається не досконало прочитаним. На жаль, праці Є. Пасічника досі не мають належних рецензій, хоча й дисертанти i словесники оперують словосполученнями на кшталт «відомий український методист». Ще бракує в науковому просторі виділення характерних рис його роботи як автора шкільних програм та підручників, що дасть можливість успішно реалізовувати освітню парадигму: учень - суб'єкт навчання - паритетний партнер спілкування. Констатуємо, що найближчим часом $є$ необхідність осмислити його чіткі рекомендації щодо літературного компонента освіти, виокремлення найбільш проблемних аспектів у галузі підручникотворення, нагадати поради спеціаліста у цій сфері. Повний аналітичний огляд наукового набутку вченого дозволить пізнати історію української школи, безперервність розвитку методичної думки протягом десятиліть.

\section{Література}

1. Пасічник Є. А. Українська література в школі / Свген Андрійович Пасічник. К. : Рад. школа, 1983. - 319 с. 2. Пасічник С. Методична наука і практика в сучасних умовах / Пасічник Є.; НПУ ім. М. П. Драгоманова // Дивослово. - 1998. - № 1. С. 50-54. 3. Пасічник Є. А. Методика викладання української літератури в середніх навчальних закладах: [навч. посіб. для студентів вищих закладів освіти]/ Євген Андрійович Пасічник. - К. : Ленвіт, 2000. - 384 с. 4. Пасічник Є. А. Шляхи підвищення ефективності викладання української мови та літератури : матеріали Всеукраїнської міжвузівської науково-практичної конференції, 17-18 листопада 1999 р./ М-во освіти і науки України, НПУ ім. М. П. Драгоманова; Редкол. Є. А. Пасічник та ін. - К. : Знання, 2000. - 216 с. 5. Пасічник Є. Актуальний і своєчасний підручник / Є. Пасічник, О. Слоньовська // Дивослово. - 2000. - № 9. С. 48-49. 6. Пасічник Є. А. Варіативність програм і підручників - це крок вперед чи 
назад? / Євген Пасічник // Українська література в школі. - 2002. - № 3. - С. 46-50. 7. Пасічник Є. Ясла повні (?) / Є. Пасічник, О. Слоньовська // Українська мова та література. - 2002. - № 22. - С. 17-21. 8. Пасічник Є. Міністр пропонує школярам малювати горщечки? // Дзеркало тижня. - № 24. - 2005. [Електронний ресурс] / Євген Пасічник. - Режим доступу: http://gazeta.dt.ua/EDUCATION/ministr_proponue_ shkolyaram.html

УДК 371.134:811

Ольга Семенова

\section{МЕТОД ПРОЕКТУВАННЯ ЯК ОДИН 3 АКТИВНИХ МЕТОДІВ ФОРМУВАННЯ ФУНКЦІОНАЛЬНОӤ КОМПЕТЕНТНОСТІ МАЙБУТНІХ УЧИТЕЛІВ ІНОЗЕМНОЇ МОВИ}

Семенова О. О. Метод проектування як один 3 активних методів формування функціональної компетентності майбутніх учителів іноземної мови.

У статті розглянуто один 3 активних методів формування функціональної компетентності майбутніх учителів іноземної мови - метод проектування. 3'ясовано проблеми компетентнісного підходу у підготовці вчителів іноземної мови.

Ключові слова: метод проектування, компетентнісний підхід, функціональна компетентність, учитель іноземної мови.

Семенова О. А. Метод проектирования как один из активных методов формирования функциональной компетентности будущих учителей иностранного языка.

В статье рассматривается один из активных методов формирования функциональной компетентности будущих учителей иностранного языка - метод проектирования. Обоснованы проблемы компетентностного подхода в подготовке учителей иностранного языка.

Ключевые слова: метод проектирования, компетентностный подход, функциональная компетентность, учитель иностранного языка.

Semenova O. O. Projecting method as one of the active methods of forming the functional competence of future foreign language teachers.

The article describes one of the active methods of forming the functional competence of future foreign language teachers - the method of projects. The author substantiates the issues concerning the competency approach while training foreign language teachers.

Key words: projecting method, competenvy approach, functional competence, foreign language teacher.

Соціально-економічні зміни в суспільстві, реформування вищої педагогічної освіти на гуманістичних та демократичних засадах потребують підвищення рівня професійної підготовки майбутніх педагогів. Від педагога в сучасних умовах вимагається здатність до інноваційної діяльності, до самостійності та нестандартності рішень, функціональної компетентності.

Компетентнісний підхід в українському освітньому просторі нині відігріє роль універсальної методологічної парадигми: змінюються основи та принципи фахової підготовки спеціаліста, вища освіта трансформується зі «знаннєвоорієнтованої», якою вона була ще із часів появи перших європейських університетів, на сучасну, «практико-орієнтовану». Компетентність педагога виявляється у трьох типових діях: 